\title{
NeuroToxicology
}

NeuroToxicology 22 (2001) 795-810

\section{Neurogenic Inflammation and Particulate Matter (PM) Air Pollutants ${ }^{\hbar}$ s}

\author{
Bellina Veronesi ${ }^{1, *}$, Marga Oortgiesen ${ }^{2}$ \\ ${ }^{1}$ National Health Effects and Environmental Research Laboratory, Cellular and Molecular Branch, \\ Neurotoxicology Division, US Environmental Protection Agency, Research Triangle Park, NC 27711, USA \\ ${ }^{2}$ Cato Research Ltd., Durham, NC 27711, USA
}

Received 29 June 2001; accepted 20 August 2001

\begin{abstract}
Exposure to a class of airborne pollutants known as particulate matter $(P M)$ is an environmental health risk of global proportions. PM is thought to initiate and/or exacerbate respiratory disorders, such as asthma and airway hyperresponsiveness and is epidemiologically associated with causing death in the elderly and those with pre-existing respiratory or cardiopulmonary disease. Plausible mechanisms of action to explain PM inflammation and its susceptible sub-population component are lacking. This review describes a series of published studies which indicate that PM initiates airway inflammation through sensory neural pathways, specifically by activation of capsaicin-sensitive vanilloid (e.g. VR1) irritant receptors. These acid-sensitive receptors are located on the sensory $C$ nerve fibers that innervate the airways as well as on various immune and non-immune airway target cells. The activation of these receptors results in the release of neuropeptides from the sensory terminals that innervate the airways. Their interactions with airway target cells, result in signs of inflammation (e.g. bronchoconstriction, vasodilation, histamine release, mucous secretion etc.). Our data have linked the activation of the VRI receptors to the surface charge carried on the colloidal particulates which constitute PM pollution. Related studies have examined how genetic and non-genetic factors modify the sensitivity of these irritant receptors and enhance the inflammatory responsiveness to PM. In summary, this review proposes a mechanism by which neurogenic elements initiate and sustain PM-mediated airway inflammation. Although neurogenic influences have been appreciated in normal airway homeostasis, they have not, until now, been associated with PM toxicity. The sensitivity of the sensory nervous system to irritants and its interactions with pulmonary target tissues, should encourage neuroscientists to explore the relevance of neurogenic influences to toxic disorders involving other peripheral target systems. Crown Copyright (C) 2001 Published by Elsevier Science Inc. All rights reserved.
\end{abstract}

Keywords: Particulate matter; Neurogenic inflammation; Tracheal epithelial cells; BEAS-2B; Somatosensory neurons; Vanilloid receptors; Capsaicin receptors; Acid-sensitive pathways

\section{INTRODUCTION AND OVERVIEW}

Exposure to airborne particulate matter (PM) air pollution is epidemiologically associated with mortality and morbidity in the international and national

is This manuscript has been reviewed by the National Health Effects and Environmental Research Laboratory, US Environmental Protection Agency, Research Triangle Park, NC and approved for publication. Approval does not signify that the contents necessarily reflect the view and policies of the Agency, endorsement, or recommendation for use.

* Corresponding author. Tel.: +1-919-541-5780;

fax: +1-919-541-4849.

E-mail address: veronesi.bellina@epamail.epa.gov (B. Veronesi). community. A mechanism of action to explain these consequences of PM exposure is lacking. Our research has demonstrated that PM initiates inflammation in airway target cells through a phenomenon known as neurogenic inflammation (NGI). This pathophysiology involves the activation of irritant receptors (vanilloid, VR1) and acid-sensitive pathways. Subsequently, pro-inflammatory neuropeptides and cytokines are released from these airway target cells and stimulate cellular expressions of airway inflammation. The discovery of these acid sensitive receptors on human respiratory epithelial cells and a description of their response to PM exposure are described in the following sections. More recent studies have addressed the 
physicochemical features of PM that are most culpable in triggering these receptors. Based on these findings, a neurogenic hypothesis has been developed suggesting that the surface charge of PM initiates airway inflammation by activation of vanilloid (i.e. capsaicin, VR1) receptors and acid-sensitive pathways. A current area of research examines the "sensitive sub-population" component of PM exposure, which renders the young, the old, and those with pre-existing cardio-pulmonary conditions especially vulnerable. This paper first provides an overview of the sensory nervous system and its role in the phenomenon of neurogenic inflammation and toxicant-induced airway disorders. A chronology of studies that have contributed to a neurogenic explanation of PM airway toxicity, follows. PM generated from industrial emissions (residual oil fly ash, coal fly ash, oil fly ash), volcanic (Mt. St. Helen), residential (woodstove) and urban ambient (St. Louis, Ottawa), were exposed to mice or cell culture models (tracheal epithelial cells, dorsal root and trigeminal ganglia neurons) of airway-relevant targets. Endpoints included single cell and population calcium recordings, RT-PCR, measures of inflammatory cytokine release, cobalt histochemistry and morphometry. The studies described in this review propose a mechanism by which neurogenic elements initiate and sustain PMmediated airway inflammation. Such neurogenic influences have been appreciated in normal airway homeostasis, but have not, until now, been associated with PM inflammation nor been implicated in its associated morbidity.

\section{Sensory Innervation of the Airways}

The nasal and pulmonary airways are innervated by central and peripheral branches of the cholinergic, noradrenergic, and adrenergic neural pathways (Barnes, 1986a, 1990; Widdicombe, 1986; de Jongste et al., 1991; Lundberg, 1995). Together and singly, they act to regulate respiratory rhythm by controlling ventilation. In addition to these classic innervation pathways, there are those, whose effects are not blocked by cholinergic or adrenergic antagonists. This "non-adrenergic-noncholinergic (NANC) innervation system, is largely sensory and derives from parasympathetic and sympathetic neurons that are located in various ganglia found along the brain stem, spinal cord and the tracheal walls (Lammers et al., 1992). Fibers from the trigeminal, dorsal root, nodose, and jugular ganglia project their fibers to the nasal, upper and lower airways. These nerve fibers are bipolar, with one axon terminating in the spinal cord or brain and the other synapsing in peripheral tissues (e.g. skin, gut and the airways) where exogenous elements are most likely to enter the body (i.e. "port of entry" tissues). In such tissues, sensory fibers can have several types of nerve terminals. Elaborate polymodal receptors (e.g. Meisner's, Pacinian) which are responsive to mechanical, vibratory and tactile stimuli, are most often found in dermal and intestinal tissues. In contrast to these, free nerve endings, lacking morphologically distinct terminals, characterize the sensory $\mathrm{C}$ fibers which innervate the airway lumen and the interstitial tissues. These free nerve endings form a structural and functional relationship with a variety of non-neuronal target cells (e.g. epithelial cells, muscle cells, mast cells and macrophages). Irritant receptors, located on the terminals of sensory fibers, are activated by noxious stimuli and modulated by endogenous inflammatory agents (e.g. bradykinin, prostaglandins, histamine). Upon their activation, a variety of neuropeptide transmitters such as substance $\mathrm{P}(\mathrm{SP})$, calcitonin gene related protein (CGRP), and neurokinin A (NKA), are released. These neurotransmitters are potent inducers of a cascade of airway inflammatory responses that include vasodilatation, mucous secretion, plasma protein extravasation, leukocyte adhesion-activation, and bronchoconstriction. These responses are caused by the interactions of peptides with immune cells and non-immune cells found throughout the "port of entry" tissues, alluded to earlier (e.g. conjunctiva, mucous membranes, skin, gut, airways). Such interactions result in the initiation of a rapid, protective response to foreign or adverse stimuli, known as 'neurogenic inflammation'. In this process, a cascade of cellular and sub-cellular events occurs, culminating in the more overt symptoms of tissue inflammation (i.e. tenderness, swelling and reddening). Historically, these symptoms have been described in vascular and immunological terms, however, more current thinking indicates that the sensory nervous system and its peptidenergic transmitters (i.e. SP, CGRP, NKA) initiate and sustain this inflammation (Barnes, 1986a, 1986b; McDonald, 1988; Solway and Leff, 1991; Meggs, 1993; Maggi, 1993; Lundberg, 1995; Baluk, 1997; Di Maria et al., 1998; Baluk et al., 1999; Joos et al., 2000). Once released, these pro-inflammatory peptides interact with a variety of immune (e.g. lymphocytes, neutrophils, macrophages, eosinophils) and non-immune (e.g. smooth muscle, endothelia cells of the vasculature, epithelial cells that line the lumen of the airways and gut, keratinocytes of the skin) target cells. In the airways, the effects of tachykinin neuropeptides are largely mediated by NK1 and NK2 receptors found on non-neural target cells. 
NKA, acting on NK2 receptors, stimulates smooth muscle contraction, while the vascular and more inflammatory effects are mediated by SP acting on NK1 receptors. NGI is often independent of higher nervous system function (i.e. central nervous system) and produces many of the overt symptoms of inflammation (e.g. erythema, edema, vasodilation, vasoconstriction, mucous secretion) through the phenomenon of the "axon reflex" (Maggi, 1993; Lundberg, 1995). Upon involvement of the immune system, the initial symptoms of inflammation are exacerbated and perpetuated, with resulting tissue damage (Joos et al., 2000).

\section{Sensory Irritant Receptors}

The sensory nervous system is especially relevant to chemically-induced airway inflammation since it functions to protect against noxious and potentially tissuedamaging stimuli. Receptors (e.g. capsaicin, acid-sensitive, mechanoreceptors) found along the distal ends of these sensory $\mathrm{C}$ fibers, are activated by a wide variety of irritants such as acid, chemical irritants, heat, cold, pressure and the botanical toxin, capsaicin. Upon their activation, a rapid influx of ions (e.g. calcium, sodium) from extracellular stores, enters the cells and stimulates the release of inflammatory neuropeptides from the distal ends of the sensory fiber (Wood and Docherty, 1997). There is an inherent age-dependent variability in the number and distribution of the irritant-sensitive receptors among species and within different tissues of the same species (Kirischuk et al., 1992; Szallasi, 1994; Szallasi and Blumberg, 1993; Acs and Blumberg, 1994). Even within the same species and cell-type (e.g. dorsal root sensory neurons), variants of the capsaicinsensitive (vanilloid or VR1) irritant receptors have been identified (Caterina et al., 1999).

Irritant receptors and neuropeptide-release are not proprietary to sensory nerve fibers. Various types of respiratory epithelial cells (e.g. neuroendocrine cells, Clara cells, and type II alveolar cells) have been shown to contain neuropeptide granules and neuropeptide receptors and have been shown to respond to neuropeptide exposure with cytokine release (Baluk et al., 1993; Mullol et al., 1997; Veronesi et al., 1999a; Stevens et al., 1997). Capsaicin-sensitivity and functional capsaicin receptors have been identified on other airway-relevant immune cells (i.e. alveolar macrophages, monocytes, RAW mono/macrophage cells) (Colquhoun et al., 1995; Garle et al., 2000; Baluk et al., 1993; Hastings and Hua, 1995; Savitha et al., 1990). In humans, inflammatory cells such as eosinophils, macrophages, epithelial cells, lymphocytes, and dendritic cells can themselves produce and release proinflammatory peptides (i.e. SP, NKA) upon irritant exposure (Joos et al., 2000). These findings indicate that, in addition to sensory neurons and their terminals, a variety of airway relevant cells contain functional irritant receptors that, when triggered by noxious stimuli (e.g. capsaicin, acid-pH, chemical irritants), release neuropeptides.

\section{Neurogenic Inflammation and Environmentally- Relevant Airway Disorders}

An impressive body of clinical and experimental literature links the hyper-vigilance of the sensory nervous system with neurogenic inflammation (NGI) in the airways (Barnes, 1986b, 1991; Meggs, 1993; Maggi, 1993; Lundberg, 1995; Widdicombe, 1996a; Baluk, 1997). The sensory nervous system and NGI is associated with the chronic inflammation and airway remodeling reported in asthmatics (Barnes, 1999; Holt et al., 1999) and that associated with respiratory irritants such as ozone (Gordon et al., 1985; Yeadon et al., 1992; Joad et al., 1996; Albright and Goldstein, 1996), sulfur dioxide (Koenig and Pierson, 1991) (el-Fawal et al., 1995), hydrogen sulfide (Prior et al., 1990), acrolein (Springall et al., 1990) and toluene diisocyanate (Sheppard and Scypinski, 1988; Gagnaire et al., 1997). Disease states such as asthma or viral infections are often marked by damage to the epithelial cell population which lines the nasal and pulmonary lumen. In such conditions, an up-regulation of neuropeptide NK1 receptors and increased sensory nerve excitability have been observed (Lundberg, 1995; Joos et al., 2000; Barnes, 1991).

The following studies implicate the sensory nervous system and NGI with the airway inflammation associated with exposure to particulate matter, a class of airborne pollutants. To demonstrate this relationship, multidisciplinary endpoints have been used that include airway hyper-responsiveness and bronchial lavage in animals and histochemical, immunocytological, biophysical, and molecular endpoints in cell culture models of sensory neurons that innervate the airways and their epithelial target cells. In these studies, PM derived from various industrial, urban ambient, industrial, residential, and volcanic sources have been used (see Table 1).

\section{PARTICULATE MATTER (PM)}

Both national and international epidemiological studies indicate a significant association between increases 
Table 1

Particulate matter air pollutants

\begin{tabular}{ll}
\hline Residual oil fly ash (ROFA) & $\begin{array}{l}\text { Collected on a Teflon glass filter from an industrial power plant (Southern Research } \\
\text { Institute, Birmingham, AL) }\end{array}$ \\
Woodstove & $\begin{array}{l}\text { Particulates collected (i.e. scraped) from the exhaust pipes of a commercially available, } \\
\text { residential woodstove in Durham, NC }\end{array}$ \\
Mt. St. Helen (MSH) & Volcanic dust collected from St. Helen in 1980 near Ritzville, WA \\
Ottawa & Urban ambient EHC-93 from Environmental Health Canada collected in bag-house in 1993 \\
St. Louis & Urban ambient ${ }^{\mathrm{a}}$ SRM 1648 \\
Coal fly ash (CFA) & Collected on glass filters from a Western US conventional coal burning power plant \\
Oil fly ash (OFA) & Industrial PM collected on Teflon-coated fiber glass filter $\left(250-300{ }^{\circ} \mathrm{C}\right)$ from the low \\
& sulfur, residual oil burning in a Niagara power plant
\end{tabular}

${ }^{a}$ Standard reference materials (SRMs) (Huggins et al., 2000) from the National Institute of Standards (Washington, DC) are shown. These PM were obtained from the Human Studies Division of the US Environmental Protection Agency, Chapel Hill, NC.

in morbidity and mortality and short-term increases in the level of the ambient PM (Samet et al., 2000). The morbidity (i.e. asthma, bronchitis, airway hyperresponsiveness) and mortality associated with PM exposure are marked by a sensitive sub-population component, characterized by increased sensitivity in the young and old, asthmatics, smokers and in those with pre-existing respiratory or cardiopulmonary conditions (Pope, 2000; Utell and Frampton, 2000). While the epidemiological association between PM pollutants and adverse health effects is clear (Dockery et al., 1992; Dockery and Pope, 1994; Schwartz, 1994, 1996; Pope, 1996, 2000; Burnett et al., 1998; Liao et al., 1999; Hoek et al., 2000), mechanisms of action to explain ambient PM toxicity and its sensitive subpopulation phenomenon are lacking.

PM comes from diverse natural (sea spray, volcanic, earth erosion) and anthropogenic (industrial, urban, residential, environmental, traffic exhaust) sources and consists of complex aggregates of elemental and organic carbons, volatile organics, metals, sulfates, pesticides, pollen, microbial contaminants and unknown materials, complexed to an insoluble carbon core. This complexity has hampered investigations into the culpable factor(s) of PM toxicity and suggests that PM may target a variety of pathways. Consequently, most experimental research has focused on the individual chemical components identified on certain industrial PM such as transition metals (Hatch et al., 1985; Gilmour et al., 1996; Pritchard et al., 1996; Dreher et al., 1997; Carter et al., 1997; Gavett et al., 1997; Kadiiska et al., 1997; Dreher et al., 1998), biologicals (e.g. endotoxins, pollen) (Becker et al., 1996), and acidic components (Chen et al., 1992; Brauer et al., 1995; Lippmann and Thurston, 1996; Kimmel et al., 1997; Zelikoff et al., 1997; Gwynn et al., 2000). In spite of the physicochemical complexity of PM, however, the levels of mortality and morbidity expressed in exposed populations are remarkably uniform across the various geographic locations in which the epidemiological studies are performed (Schwartz, 1994; Utell and Frampton, 2000). This uniformity is preserved even when epidemiological data from areas with widely varying emission sources are compared (Utell et al., 1991; Dockery and Pope, 1994; FinlaysonPitts and Pitts, 1997; Samet et al., 2000). This relationship suggests that PM may be affecting toxicity through a more common physicochemical mechanism.

\section{EXPERIMENTAL CHRONOLOGY}

\section{Respiratory Epithelial Cells Contain Sensory Receptors}

Sensory C nerve fiber terminals and their epithelial target cells constitute the initial cellular unit to encounter airborne pollutants. Unfortunately, their interactions in response to chemical irritants and the subsequent inflammatory cascade, are poorly understood. Consequently, these interrelationships were examined using a human, immortalized, trachealbronchial epithelial cell line (BEAS-2B) (Reddel et al., 1988). These respiratory target cells have been featured in numerous studies involving airborne pollutants (Samet et al., 1992; McKinnon et al., 1993; Carter et al., 1997), and show inflammatory responses remarkably similar to human primary epithelial cultures.

BEAS-2B cells were first examined for their response to physiological concentrations of $\mathrm{SP}$, acid $(\mathrm{pH}$ 6.5-5.0), or the biological irritant, capsaicin. Exposure of SP resulted in immediate increases in intracellular calcium concentration (i.e. $\left[\mathrm{Ca}^{2+}\right]_{\mathrm{i}}$ ), the synthesis $2 \mathrm{~h}$ later of transcripts for the pro-inflammatory cytokines, IL-6, IL- 8 and $\mathrm{TNF} \alpha$, and the subsequent release 

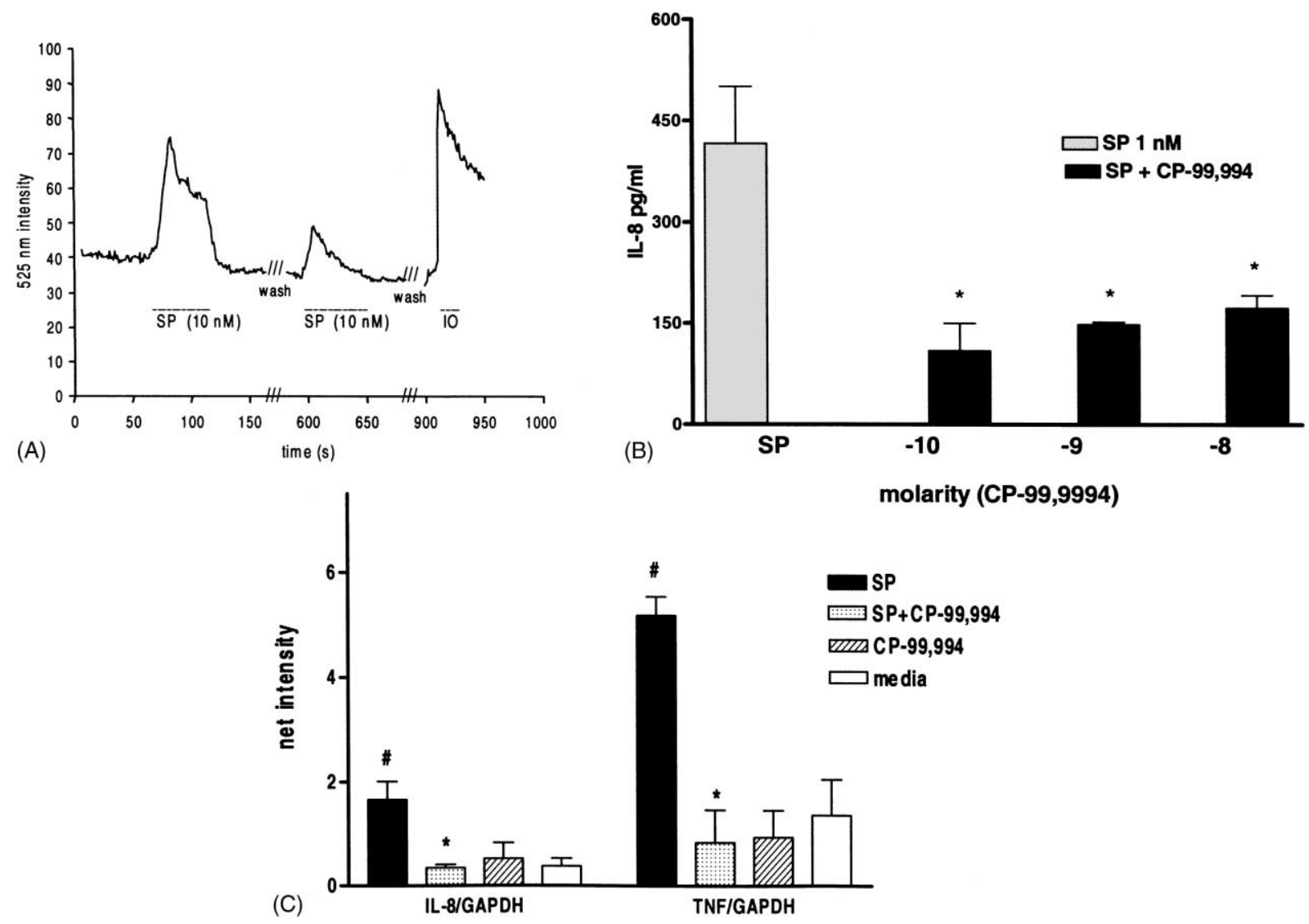

Fig. 1. (A) Increases in $\left[\mathrm{Ca}^{2+}\right]_{\mathrm{i}}$ levels were measured in BEAS-2B cells using the fluorescent probe Fluo-3 AM. Exposure to SP (10 nM) produced a rapid increase in $\left[\mathrm{Ca}^{2+}\right]_{i}$, followed by a lower, longer lasting plateau. A second exposure of the cells to $\mathrm{SP}$ produced a $\left[\mathrm{Ca}^{2+}\right]_{\mathrm{i}}$ response with a smaller peak amplitude, suggesting receptor desensitization or internalization. IO $(2 \mu \mathrm{M})$ was applied at the end of each experiment to determine the maximal $\left[\mathrm{Ca}^{2+}\right]_{\mathrm{i}}$ increase. (B) BEAS-2B cells were also pretreated with 0.1-10 nM CP-99,994, a non-peptide, competitive antagonist of the NK1 receptor before exposure to SP $(1 \mathrm{nM})$. IL-8 release was significantly reduced at all concentrations of the antagonist. Media values are subtracted from all treatment groups. Significance $(P<0.05)$ from controls is denoted by $(*)$. (C) RT-PCR data on inflammatory cytokine transcript levels indicated that transcripts for IL-8, and TNF $\alpha$ were significantly depressed in cultures treated with CP-99,994 $(1 \mathrm{nM})$ before a $2 \mathrm{~h}$ exposure to SP $(10 \mu \mathrm{M}, 1 \mathrm{nM})$. The symbol (\#) indicates significance $(P<0.05)$ from media controls and asterisks $(*)$ indicate significance $(P<0.05)$ from SP-treated cells. Reproduced with permission (Veronesi et al., 1999a).

of these cytokines, $4 \mathrm{~h}$ post-exposure. Moreover, this release occurred in a receptor-mediated fashion, since cytokine transcripts and their proteins were reduced by pretreatment with antagonists to NK1 receptors (Fig. 1). Acid $\mathrm{pH}$ and capsaicin also stimulated increases in $\left[\mathrm{Ca}^{2+}\right]_{\mathrm{i}}$ and the release of inflammatory cytokines (Fig. 2), changes which were partially inhibited by amiloride and by the capsaicin receptor antagonist, capsazepine (CPZ) (Bevan et al., 1992). BEAS-2B cells, identified as capsaicin or acid-sensitive by a cobalt-based histochemical technique (Wood et al., 1988), were morphometrically analyzed to show a concentration-dependent response of the cobalt precipitate in response to both acid $\mathrm{pH}$ and capsaicin. Together, these studies (Veronesi et al., 1999a) indicated that human tracheal-bronchial epithelial cells (i.e. BEAS-2B) housed irritant receptors and acid-sensitive pathways, which when triggered, released inflammatory cytokines.

\section{Role of VR1 Receptors in ROFA Inflammation}

To address the possibility that PM could initiate inflammation through a NGI mechanism, residual oil fly ash (ROFA), an industrial emission source PM pollutant, was first tested. ROFA is generated from the burning of low sulfur residual oil, and is composed primarily of highly soluble transition metals and sulfates (Henry and Knapp, 1980; Pritchard et al., 1996; Dreher et al., 1997). Although ROFA is atypical relative to ambient PM in terms of its chemical make-up and in the level of its associated inflammation in experimental models, it contains components (i.e. metals, sulfates, acids) that could be relevant to the 

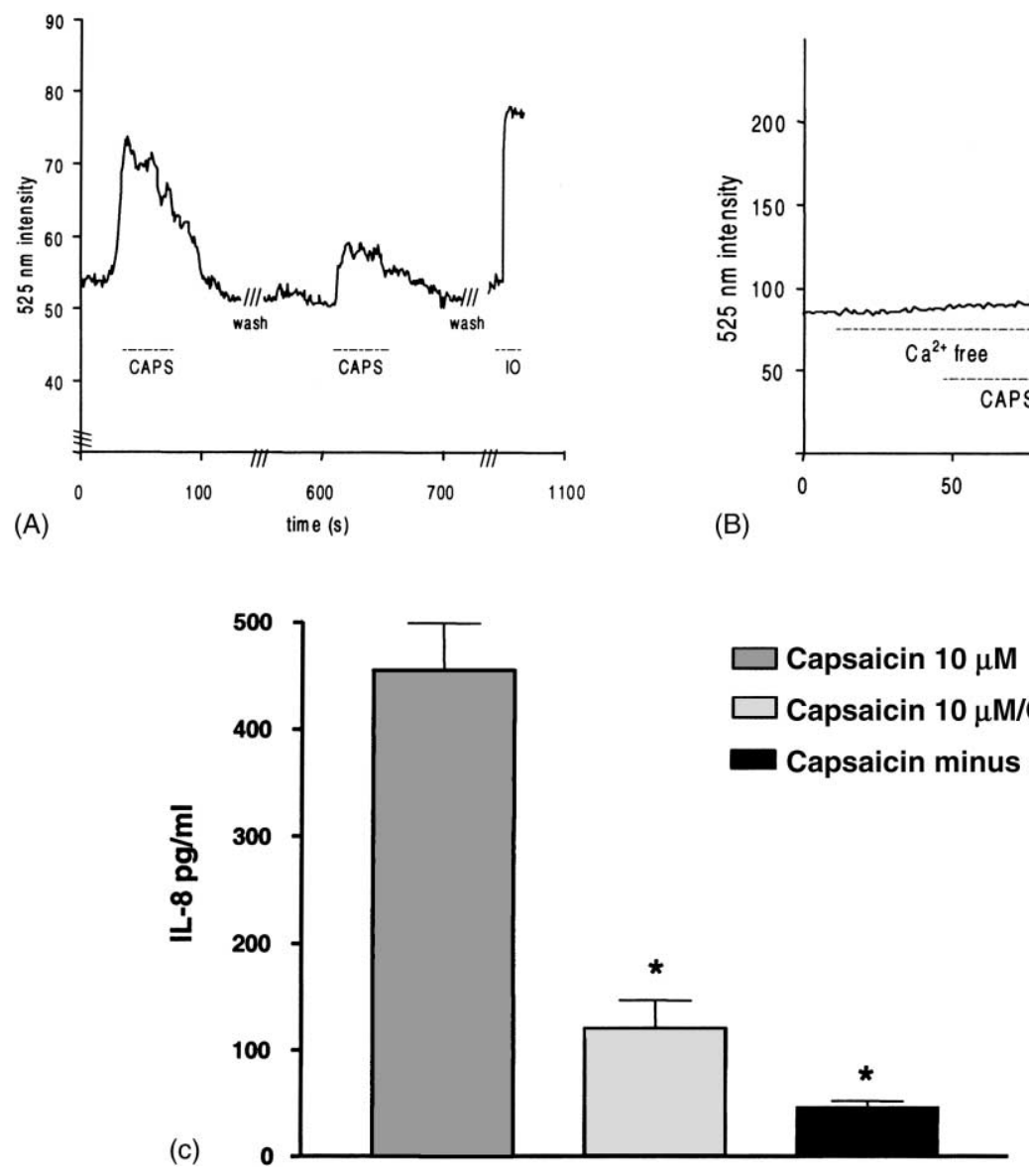

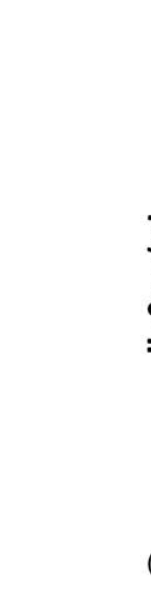

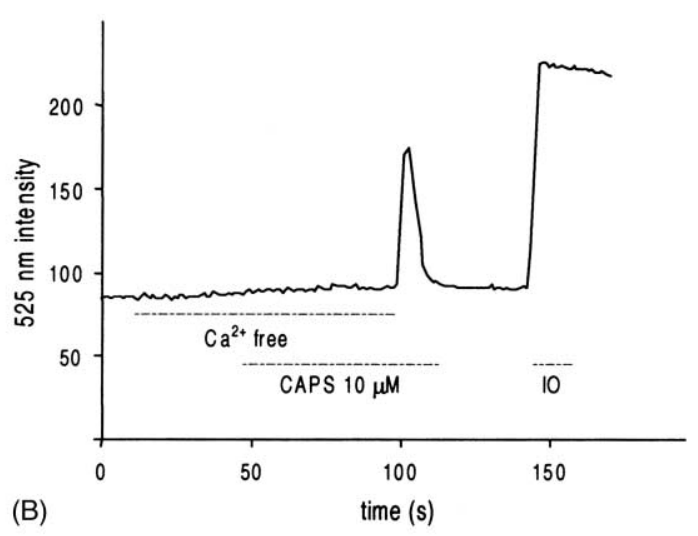

(B)

Fig. 2. (A) Cells, exposed to $10 \mu \mathrm{M}$ capsaicin (CAPS) produced a rapid increase in $\left[\mathrm{Ca}^{2+}\right]_{\mathrm{i}}$ that declined over time. After washing, a second exposure to CAPS $(10 \mu \mathrm{M})$ increased $\left[\mathrm{Ca}^{2+}\right]_{\mathrm{i}}$ but with a reduced response amplitude, suggesting receptor desensitization. (B) Increases of $\left[\mathrm{Ca}^{2+}\right]_{\mathrm{i}}$ did not occur when cells were bathed in calcium-magnesium-free HEPES buffer. When the wash solution was changed to one containing CAPS $(10 \mu \mathrm{M})$ in calcium-magnesium media, an immediate increase in $\left[\mathrm{Ca}^{2+}\right]_{\mathrm{i}}$ occurred. (C) Capsaicin $(10 \mu \mathrm{M})$ stimulated IL8 release after $4 \mathrm{~h}$ exposure. This release was significantly $(*)$ reduced $(>75 \%)$ by pre-exposure to CPZ $(12 \mathrm{mM})$, an antagonist of VR1 receptor(s). BEAS-2B cells, exposed to capsaicin in calcium-magnesium-free media, failed to release IL-8. Media values were subtracted from all treatment groups. Reproduced with permission (Veronesi et al., 1999a).

underlying mechanisms of PM inflammation. Tracheal instillation of ROFA in mice and rats produces airway hyper-responsiveness and acute lung injury, consisting of epithelial damage, pulmonary edema, hemorrhage, and influx of neutrophils, macrophages, and eosinophils (Su et al., 1995; Dreher et al., 1997; Dye et al., 1997; Kodavanti et al., 1997a). ROFA also produces a species-dependent oxidative burst, inflammatory cytokine release and apoptosis when exposed to cultures of alveolar macrophages (Becker et al., 1996; Rahman et al., 1997; Holian et al., 1998). Human primary bronchial epithelial cells and the immortalized BEAS-2B cells, release various cytokines (i.e. IL-6, IL-8, TNF $\alpha$ ) and inflammatory mediators in response to ROFA (Carter et al., 1997). Sub-cellular changes associated with ROFA exposure include alterations in signal transduction (Samet et al., 1997; Baeza-Squiban et al., 1999), and free radical formation due to its high transition metal content ( $\mathrm{Li}$ et al., 1996; Dye et al., 1997).

Since we had shown that respiratory epithelial cells contained both neuropeptide and acid-sensitive irritant receptors and pathways (Veronesi et al., 1999a), their role in the cellular inflammation associated with ROFA exposure was examined (Fig. 3). ROFA-exposed BEAS-2B cells responded with an immediate increase in $\left[\mathrm{Ca}^{2+}\right]_{i}$ followed by a concentration-dependent release of IL- 6 . To test the relevance of neuropeptide or capsaicin receptors to these changes, BEAS-2B cells were pretreated with neuropeptide receptor antagonists (CP-99,994, CGRP 8-32) or CPZ, the antagonist for the capsaicin (i.e. VR1) receptor. Although antagonists to the NK1 and CGRP receptors reduced ROFAstimulated IL- 6 cytokine production by $\sim 25$ and $50 \%$, pretreatment of cells with CPZ inhibited the immediate increases in $\left[\mathrm{Ca}^{2+}\right]_{i}$, diminished transcript (i.e. IL-6, 

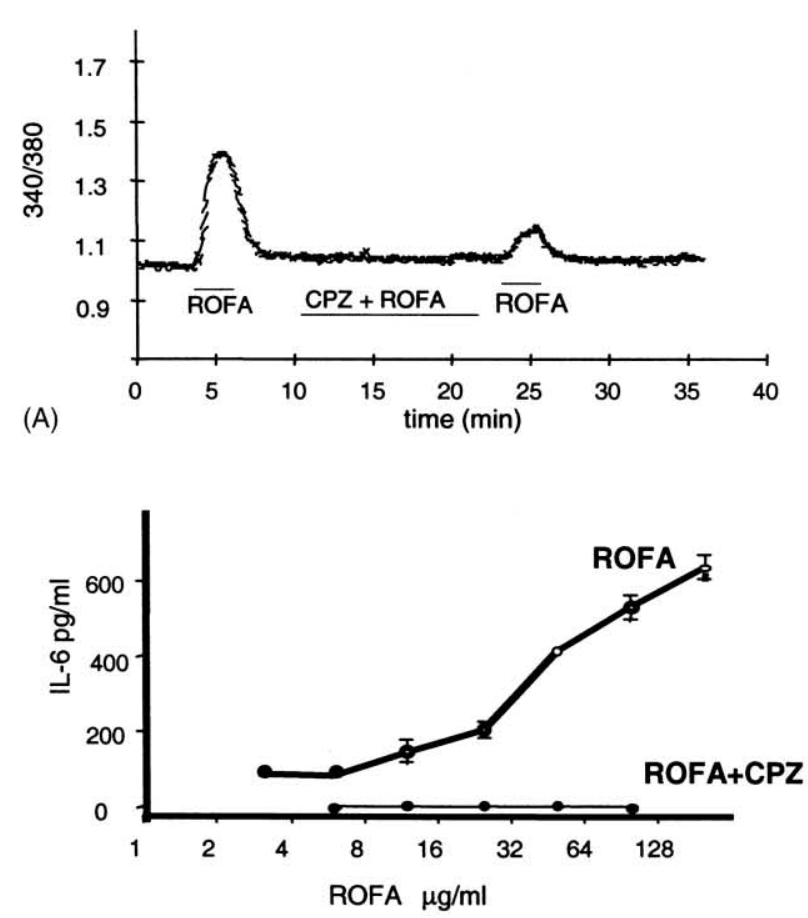

(C)

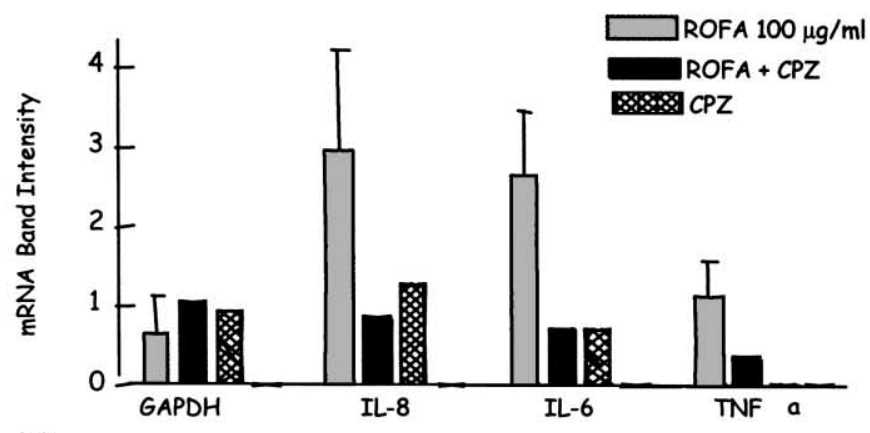

(B)

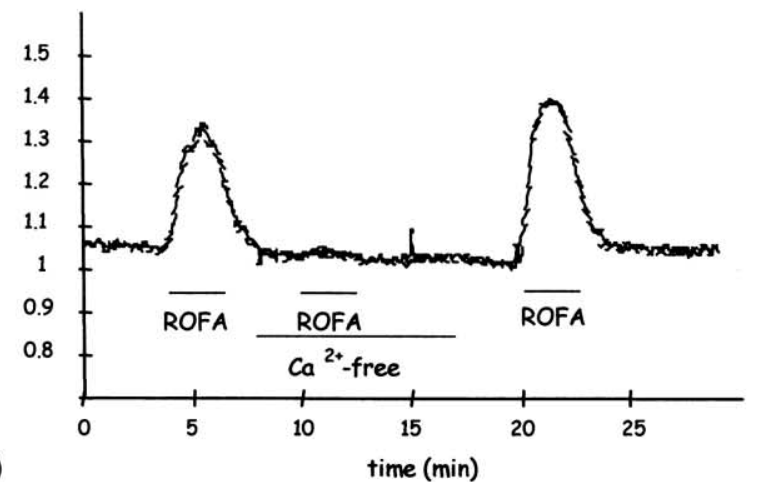

Fig. 3. Pretreatment of BEAS-2B with CPZ $(5-20 \mu \mathrm{M})$, the antagonist to the VR1 capsaicin receptor, (A) inhibited the ROFA-induced increase in $\left[\mathrm{Ca}^{2+}\right]_{\mathrm{I}}$, (B) reduced pro-inflammatory transcripts for IL-8, IL-6 and TNF $\alpha$ cytokines; and (C) reduced the IL-6 release in BEAS-2B cells to control levels. (D) The ROFA response was also abolished in the absence of extracellular calcium. Reproduced with permission (Veronesi et al., 1999b).

IL-8, TNF $\alpha$ ) levels and reduced IL-6 cytokine release to control levels. In addition, these experiments showed that such changes were dependent on extracellular calcium, a characteristic of capsaicin-sensitive receptors (Winter et al., 1993; Kuenzi and Dale, 1996).

ROFA, and other PM stimulate a variable release of inflammatory cytokines and an oxidative burst and apoptosis in human alveolar macrophages (HAM) (Becker et al., 1996). HAM, pre-exposed to CPZ (15 min) before ROFA exposure, prevented this oxidative burst (as measured by chemiluninescence) (Mudpalli, 1999). Subsequent studies indicated that apoptosis could also be blocked in ROFA-exposed HAM or in a mouse macrophage/monocyte cell line (i.e. RAW 254) that had been pretreated with a variety of non-cytotoxic concentrations CPZ (Becker, and Veronesi, unpublished data).

The inflammation and airway hyper-responsiveness associated with a variety of air pollutants are reduced in animals whose sensory fibers have been destroyed by capsaicin-treatments or interrupted with antagonists to neuropeptide or capsaicin receptors (Prior et al., 1990; Nielsen, 1991; Yeadon et al., 1992; Satoh et al., 1993; Scheerens et al., 1996). The relevance of sensory innervation and its irritant receptors to ROFA inflammation was subsequently examined in a murine model of airway hyper-responsiveness. BALB/c mice were denervated of polymodal sensory $\mathrm{C}$ fibers by neonatal capsaicin treatment (Hayes et al., 1981) and as adults administered ROFA by tracheal instillation. These "sensory denervated" animals showed a significant reduction in airway hyper-responsiveness, inflammatory cell (neutrophils) influx and LDH release relative to normal mice exposed to ROFA (Gavett et al., 1998). To replicate this phenomenon in culture, sensory ganglia cultured from these denervated animals, failed to release cytokines in response to a variety of irritants and PM (Fig. 4).

Taken collectively, these data indicated that the capsaicin-sensitive sensory system and its associated acid-sensitive irritant receptors played an initiating role in ROFA inflammation in two critical human airway target cells (i.e. tracheal epithelial cell, alveolar macrophage) and in whole animals.

\section{ROFA "Surrogates"}

PM is marked by an extreme heterogeneity in its physicochemical make-up, a complexity which has resulted in a variety of hypotheses that associate the 


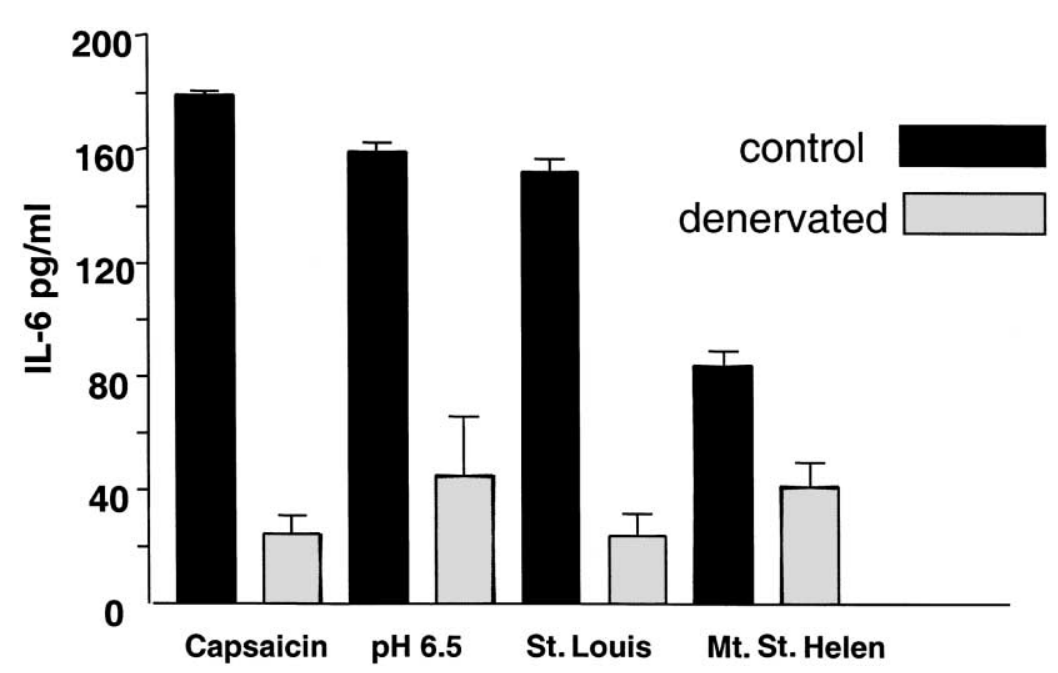

Fig. 4. BALB/c mice were denervated of polymodal sensory $\mathrm{C}$ fibers by neonatal capsaicin treatment. Sensory neurons, dissected from the DRG ganglia of these denervated animals and exposed to various PM $(50 \mathrm{mg} / \mathrm{ml})$ or prototype irritants failed to release IL-6 in response, implicating the sensory $\mathrm{C}$ fibers as critical to cytokine release in response to PM.

individual components of PM with inflammatory changes. The next series of experiments used charged, plastic synthetic particles to examine what physicochemical properties of ROFA were most responsible for activating the irritant-sensitive pathways. Principles of surface chemistry (Hunter, 1981) indicate that colloidal particles (like ROFA and other PM) carry an inherently negative surface charge (i.e. zeta potential) which attracts protons from their fluid milieu. These protons surround the individual particles, neutralizing their negative surface charge and forming a positive (i.e. acid) cloud around the individual particle (i.e. surface of shear) that has a physical dimension and a distinct electrical charge that relates to its original electronegativity (Hunter, 1981).

Since irritant receptors were purported to be sensitive to acidity (i.e. protonic charge), experiments were designed to examine if the surface charge of ROFA could stimulate inflammation. For this, the size of ROFA "field" (i.e. emission source) particles was measured microscopically $(1-10 \mu \mathrm{m})$. Next, the velocity of the suspended ROFA particles was measured by microelectrophoresis and from these data, the zeta potential was calculated using the Helmholtz-Smoluchowski formula (Sennet and Olivier, 1965). By these measures, ROFA particles were shown to carry a negative surface charge, with an average zeta potential of $-28 \pm 1.3 \mathrm{mV}$. This value indicated that the proton concentration surrounding ROFA particles would be higher in its microenvironment relative to its surrounding solution. Thus, ROFA particles would carry a protonic micro-environment, even when suspended in a neutral buffer. We proposed that this acidic micro-environment would be sufficient to activate acid-sensitive receptors (i.e. VR1) and pathways in the airways. To examine this, $2-$ $6 \mu \mathrm{m}$ diameter synthetic polymer microspheres (i.e. polymethacrylic acid nitrophenylacrylate microspheres, SPM) were prepared (Eichenbaum et al., 1998) and electronegatively charged $(-29 \pm 0.9 \mathrm{mV})$. $\mathrm{mV}$ ). These SPM synthetics acted as surrogates of ROFA particles with respect to their size and surface charge, but lacked other contaminants that were thought to be responsible for its toxicity (e.g. transition metals, sulfates, volatile organics and biologicals). The effects of SPM on biological activation (i.e. increases in $\left[\mathrm{Ca}^{2+}\right]_{\mathrm{i}}$, IL-6 release) were examined in trachealbronchial epithelial cells (i.e. BEAS-2B) and mouse dorsal root ganglia (DRG) sensory neurons that innervate the tracheal airways. These sensory neurons are known to contain abundant neuropeptide and irritant receptors, similar to those found on their fiber extensions (Baccaglini and Hogan, 1983; Gold et al., 1996; Kress et al., 1997). When these receptors are activated by irritants, they respond with a rapid increase in $\left[\mathrm{Ca}^{2+}\right]_{\mathrm{i}}$, and the subsequent release of inflammatory cytokines (i.e. IL-6) and neuropeptides from their cell bodies (Murphy et al., 1995; Marz et al., 1998).

Sensory neurons and BEAS-2B were exposed to equal numbers of ROFA or SPM particles. Biological activation (i.e. increase in $\left[\mathrm{Ca}^{2+}\right]_{i}$, IL-6 release) occurred in both cell types in response to either ROFA or SPM and both responses could be reduced by either antagonist to acid-sensitive pathways (Fig. 5). Final experiments showed that neutrally charged SPM (i.e. zeta potential of $0 \mathrm{mV}$ ) did not produce increases in $\left[\mathrm{Ca}^{2+}\right]_{\mathrm{i}}$ or IL-6 release (Oortgiesen et al., 2000). 

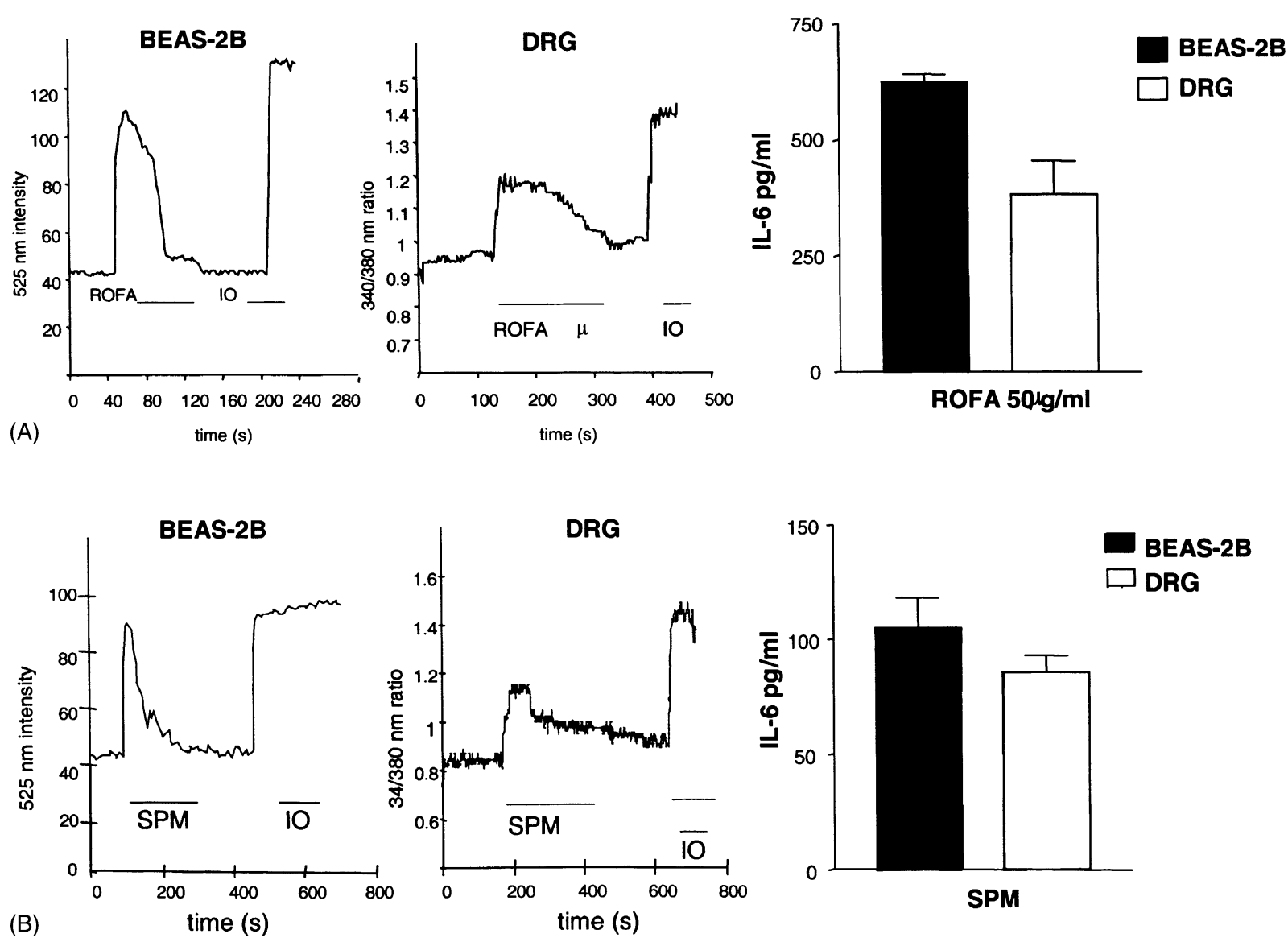

Fig. 5. DRG and BEAS-2B cells responded to (A) ROFA $(50 \mathrm{mg} / \mathrm{ml})$ or $(\mathrm{B}) \mathrm{SPM}\left(2 \times 10^{4}\right.$ particles/ml $)$ with similar increases in $\left[\mathrm{Ca}^{2+}\right]_{\mathrm{i}}$ and cytokine release. Reproduced with permission (Oortgiesen et al., 2000).

\section{Physicochemical Aspects of PM Inflammation}

To expand on this observation, a larger set of PM was obtained (Table 1) from various urban (St. Louis, Ottawa), residential (Woodstove), volcanic (Mt. St. Helen), and industrial (oil fly ash, coal fly ash) sources. Morphometric analysis of microscopically visible $(\geq 2 \mu \mathrm{m})$ particles, suspended in buffer, indicated that each "field" (i.e. primary source) PM contained different numbers and sizes of particles. Each "field" PM was then separated into particulate and soluble fractions and described physicochemically (i.e. size and number of visible particles, acidity, zeta potential). BEAS-2B epithelial cells were next exposed to each fraction of the various PM and their biological effects (i.e. increases in $\left[\mathrm{Ca}^{2+}\right]_{\mathrm{i}}$, IL-6 release) were measured and related to their physicochemical descriptions. When examined by linear regression analysis, the only physicochemical property that correlated with increases in $\left[\mathrm{Ca}^{2+}\right]_{\mathrm{i}}$ and IL-6 release was the surface charge (i.e. zeta potential) of the various particulate fractions $\left(r^{2} \geq 0.97\right)$ (Veronesi et al., in press).

\section{Hypothesis}

Based on above studies, we hypothesized that the acidic micro-environments associated with negativelycharged colloidal PM particles, activated acid-sensitive receptors and pathways located on airway target cells. This neurogenic activation resulted in an immediate influx of calcium, which in turn, caused both the release of neuropeptides from sensory terminals and a more protracted release of inflammatory cytokines from sensory neurons and other airway target (e.g. epithelial) cells. Neuropeptides and cytokines then proceeded to initiate and sustain inflammatory events in the airways through the phenomenon of NGI.

\section{SUSCEPTIBLE POPULATIONS}

\section{VR1 Irritant Receptors Linked to PM Inflammatory Response}

Epidemiological studies suggest that susceptibility to PM air pollutants is variable among sensitive 
populations (i.e. the young, the elderly, those with preexisting respiratory and cardiopulmonary conditions). Demographics, life-style (e.g. smoking), and pre-existing pathologies have been proposed to explain this variability (Dockery and Pope, 1994; Pope, 2000; Utell and Frampton, 2000). Animal studies of pollutant-induced airway inflammation are also marked by species and strain differences. Genetic differences are thought to underlie these variations and have been experimentally demonstrated for ozone (Kleeberger, 1995; Zhang et al., 1995), nitrogen dioxide (Holroyd et al., 1997) and diesel exhaust (Ichinose et al., 1997; Miyabara et al., 1998). Several studies also indicate that the airway inflammation and hyper-responsiveness that occur with ROFA exposure are strain- and species-specific (Gavett et al., 1998; Kodavanti et al., 1997b).

To investigate the underlying causes of this selective susceptibility, we exposed BALB/c and C57blk/6 (i.e. B6) mice intratracheally to ROFA and examined them for signs of airway inflammation. Bronchial lavage of $\mathrm{BALB} / \mathrm{c}$ mice showed significantly higher numbers of neutrophils and increased airway hyper-responsiveness in response to methacholine challenge, whereas B6 mice showed no significant change in either inflammatory endpoint. To examine the mechanism of this strain specificity to PM, cultures of DRG sensory neurons, which innervate the upper airways in situ, were explanted from both BALB/c and B6 fetal mice and exposed to ROFA, woodstove dust, ambient PM from Ottawa and St. Louis, coal fly ash and oil fly ash or to prototype irritants (e.g. capsaicin, acid pH). These data showed that DRG neurons from BALB/c mice consistently released significantly higher levels of the pro-inflammatory cytokine IL-6 into their nutrient media relative to neurons from B6 mice (Fig. 6). DRG neurons cultured from BALB/c and B6 neonates, were also examined by calcium imaging for changes in response to acid $\mathrm{pH}(5.0,6.5)$ or to the botanical toxin, capsaicin. These data showed that significantly higher numbers of $\mathrm{BALB} / \mathrm{c}$ neurons responded to these prototype irritants with increases in $\left[\mathrm{Ca}^{2+}\right]_{i}$, relative to $\mathrm{B} 6$ neurons. Morphometric analysis of BALB/c neurons, histochemically stained with cobalt to label neurons bearing capsaicin-sensitive (i.e. VR1) receptors, showed a significantly higher level of stained neurons relative to B6 neurons. Finally, semi-quantitative RTPCR showed a higher expression of VR1 receptor mRNA in DRG taken from neonatal BALB/c mice relative to B6 mice (Veronesi et al., 2000). Subsequent experiments, using similar techniques (i.e. RT-PCR, cobalt histochemistry and immunocytochemistry), demonstrated a higher expression of SP (NK1) neuropeptide receptors and release of neuropeptides in

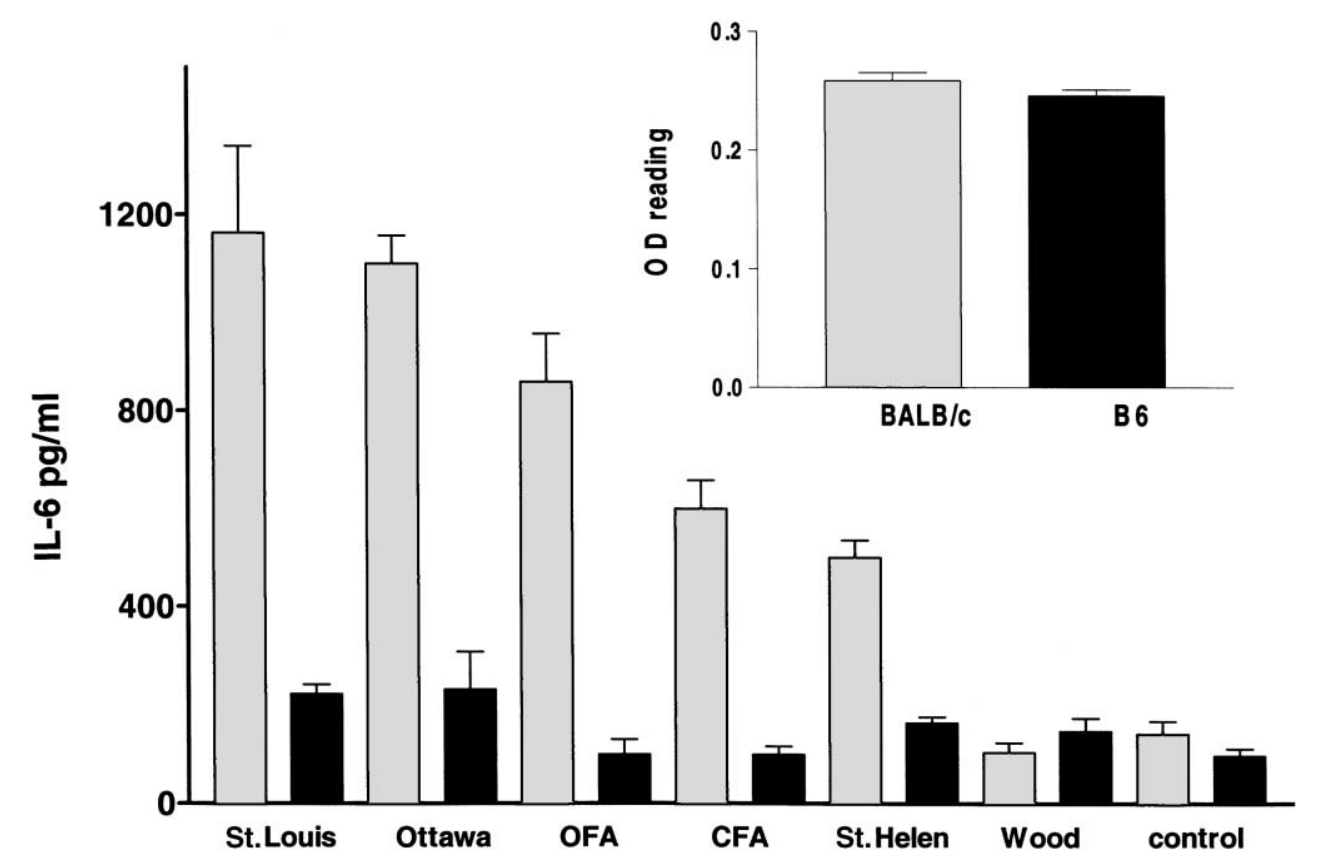

Fig. 6. DRG neurons, dissociated from fetal BALB/c and B6 mice were exposed to various PM (50 $\mu \mathrm{g} / \mathrm{ml})$ for $4 \mathrm{~h}$. In all instances, except for woodstove, BALB/c released significantly higher levels of IL-6 relative to B6 $(P<0.05)$. A neutral red viability/cytotoxicity (inset) showed no differences in BALB/c and B6 control cultures at the time of PM treatment. DRG were isolated, cultured at identical cell densities $\left(2 \times 10^{5} \mathrm{cell} / \mathrm{ml}\right)$, and exposed under similar conditions. OFA: oil fly ash, CFA: coal fly ash, MSH: Mt. St. Helen. Reproduced with permission (Veronesi et al., 2000). 
response to PM in sensory neurons taken from BALB/c mice relative to the $\mathrm{B} 6$ strain.

Taken together, the above in vivo and in vitro studies suggested that the variable inflammatory sensitivity to $\mathrm{PM}$ observed in different mouse strains (i.e. BALB/c, B6) related to quantitative differences in the neuropeptide, VR1 receptors and acid-sensitive pathways found on sensory neurons that innervate the nasal and upper pulmonary airway. Such data showed how geneticallydetermined differences in sensory neural pathways could influence expressions of PM-induced airway inflammation. Current experiments are directed at understanding how non-genetic factors can alter PM sensitivity through neurogenic pathways.

\section{Non-Genetic Factors that Affect VR1 Receptor Sensitivity}

\section{Cell-Cell Interactions: Neuron-Glia Relationships}

Neuron-glial interactions are reported to influence receptor sensitivity and cell sensitivity to chemical toxicants (McMillian et al., 1995; Brismar, 1995; Belmonte et al., 1996). DRG somatosensory neurons and their peripheral extensions are surrounded by several types of glia (e.g. satellite cells, astrocytes, Schwann cells) which contain neuropeptide and capsaicin receptors (Brismar, 1995; Palma et al., 1997). Preliminary data indicate that cultured glial cells found in the DRG's environment respond to $\mathrm{PM}$, acid $\mathrm{pH}$ and capsaicin with increases in $\left[\mathrm{Ca}^{2+}\right]_{i}$ and inflammatory cytokine release and that the reduction of this glial environment with anti-mitotic treatments (e.g. arabinoside) significantly enhances IL-6 release in DRG sensory neurons exposed to PM (Fig. 7). Such data suggest that disruption of the sensory neuron-glia integrity in situ can alter (i.e. enhance) the receptor-mediated sensitivity to PM, an observation that carries clinical significance since various metal toxicants (e.g. methyl mercury, tellurium) and pharmaceuticals (e.g. taxol, cisplatin) are known to damage the peripheral and central glial population (Thomas et al., 1988; Hoi et al., 1994; Aschner, 1998).

\section{Cell-Cell Interactions: Neuron-Epithelial Relationships}

In normal physiological settings, the respiratory epithelial population and its sensory innervation act reciprocally to influence the growth, differentiation, and homeostasis of each other (Chan and Haschke, 1985; Garcia-Hirschfeld et al., 1994; White et al., 1995; Belmonte et al., 1996). These relationships are especially critical to the organism's inflammatory response (Hoyle et al., 1998; Ogun-Muyiwa et al., 1999; Shu and Mendell, 1999). The epithelial brush border which line the tracheal-bronchial airways contain neutral endopeptidase (NEP), an enzyme which acts to deactivate inflammatory neuropeptides (e.g. substance P) released by the sensory nerve fibers (Devillier et al., 1988; Piedimonte et al., 1992; Di Maria et al., 1998). Since the epithelial cells, and their

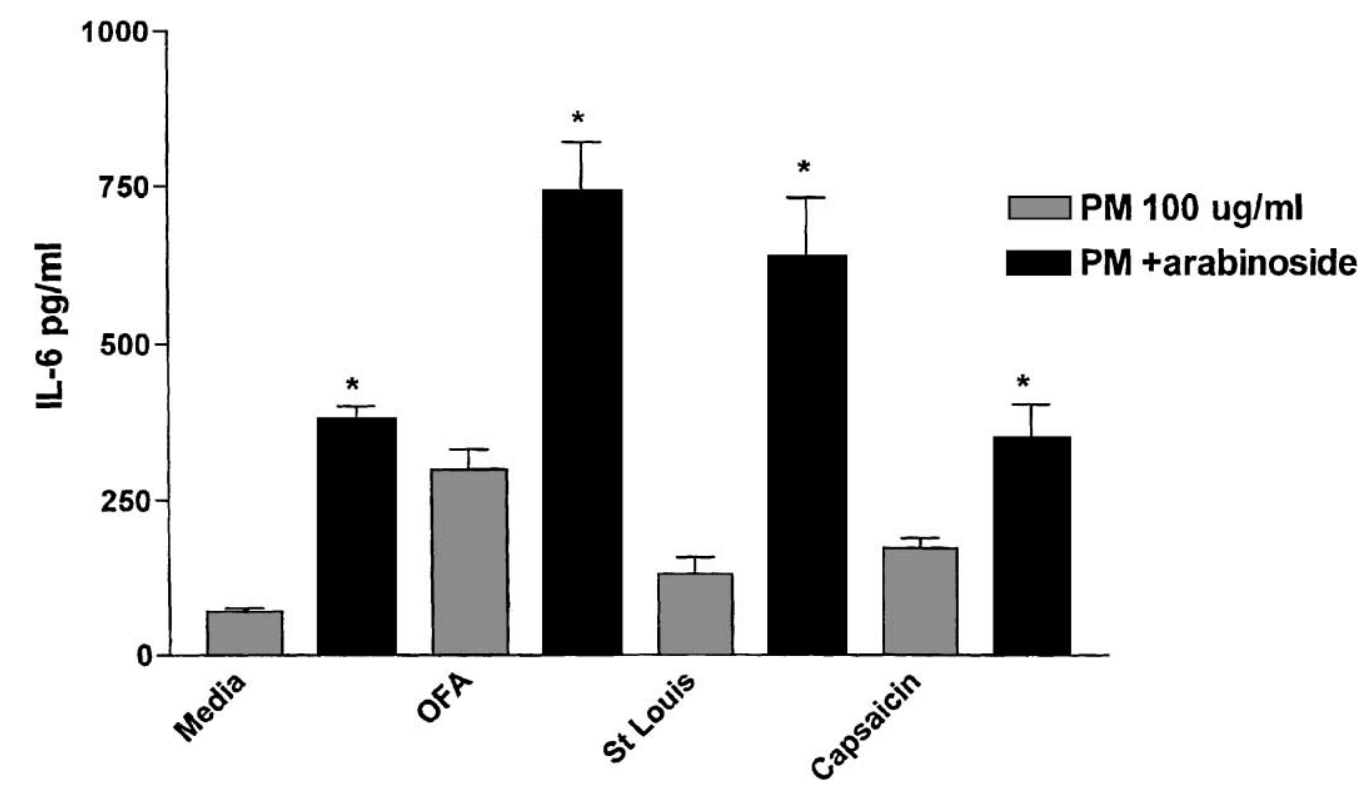

Fig. 7. DRG were cultured in the presence or absence of their glial environment by cytosine arabinoside $(6 \mu \mathrm{M})$ treatment for $48 \mathrm{~h}$. Both cultures were then exposed for $4 \mathrm{~h}$ to various PM $(100 \mathrm{mg} / \mathrm{ml})$. DRG were isolated and cultured at the same cell densities and exposed under similar conditions. Significance $\left({ }^{*} P<0.05\right)$ is indicated. 
sensory C fibers terminals are the initial targets of inhaled PM (Ohtoshi et al., 1994; Mills et al., 1999), studies were designed to examine their relative biological response to PM. BEAS-2B epithelial cells and DRG neurons were exposed at equivalent concentrations and exposure times to PM from industrial, ambient, residential, and volcanic sources. In all instances, sensory neurons released 10-200-fold higher levels of IL-6 relative to epithelial cells (Veronesi et al., in press). This disproportionate inflammatory response of two critical airway target cells may be relevant to the susceptible population component of PM inflammation since many examples of respiratory disorders (e.g. asthma, chronic allergen exposure, viral respiratory infections (Lazarus, 1986; Wasserman, 1988; Tonnel et al., 1992; Elwood et al., 1993; Ladenius et al., 1995; Widdicombe, 1996b; Folkerts and Nijkamp, 1998; Polito and Proud, 1998) and conditions associated with chemical pollutants (e.g. cigarette smoke toluene diisocyanate, ozone) (Gordon et al., 1985; Laitinen et al., 1985; Tonnel et al., 1992; Khair et al., 1996; Baeza-Squiban et al., 1999) are characterized by damage to the epithelial barrier that lines the airways. Such damage, not only results in the loss of critical neuropeptide deactivating enzymes (e.g. NEP), but allows the sensory fiber to physically extend closer to the airway lumen and in closer proximity to the inhaled PM particles. These data (Veronesi et al., in press) which show a higher inflammatory sensitivity of sensory neurons relative to the epithelial cell population, suggest that disruption of the epithelial barrier lining the lumen would result in enhanced and prolonged inflammatory events. Although ambient levels of particulates, vapors, and aerosol pollutants may have little consequence to healthy individuals whose lungs have intact epithelial linings, those sensitive individuals whose epithelial lining is damaged (e.g. smokers, asthmatics, elderly) would experience an increased inflammatory response to PM and other pollutants.

\section{SUMMARY}

The studies described in the present review support a neurogenic explanation for the inflammation associated with PM air pollution collected from multiple sources. Our data report that airway cells initially targeted by the inhaled PM contain acid-sensitive irritant receptors whose activation by the surface charge carried on PM particles results in cellular inflammation. A neuroimmunological mechanism in the initiation of PM-associated airway inflammation is plausible since sensory receptors are highly sensitive indicators of noxious and potentially damaging chemical exposure. This neurogenic hypothesis has been used to examine the sensitive sub-population component of PM and current research extends this dataset by examining how non-genetic factors (i.e. cell-cell interactions) modifies receptor sensitivity. Such studies promise to offer insight into predisposing or acquired conditions that may contribute to the sensitive subpopulation phenomenon of PM exposure. This neuroimmunological explanation for PM inflammation, while novel, is firmly supported by neurobiological, immunological, and pulmonary interactions which culminate in the pathophysiology of neurogenic inflammation.

\section{REFERENCES}

Acs G, Blumberg PM. Comparison of $[3 \mathrm{H}]$ resiniferatoxin binding to spinal cord and dorsal root ganglia of newborn and adult rats. Life Sci 1994;54(24):1875-82.

Albright JF, Goldstein RA. Airborne pollutants and the immune system. Otolaryngol Head Neck Surg 1996;114(2):232-8.

Aschner M. Astrocytes as mediators of immune and inflammatory responses in the CNS. Neurotoxicology 1998;19(2):269-82.

Baccaglini PI, Hogan PG. Some rat sensory neurons in culture express characteristics of differentiated pain sensory cells. Proc Natl Acad Sci USA 1983;80(2):594-8.

Baeza-Squiban A, Bonvallot V, Boland S, Marano F. Airborne particles evoke an inflammatory response in human airway epithelium: activation of transcription factors. Cell Biol Toxicol 1999;15(6):375-80.

Baluk P. Neurogenic inflammation in skin and airways. J Investig Dermatol Symp Proc 1997;2(1):76-81.

Baluk P, Nadel JA, McDonald DM. Calcitonin gene-related peptide in secretory granules of serous cells in the rat tracheal epithelium. Am J Respir Cell Mol Biol 1993;8(4):446-53.

Baluk P, Thurston G, Murphy TJ, Bunnett NW, McDonald DM. Neurogenic plasma leakage in mouse airways. Br J Pharmacol 1999;126(2):522-8.

Barnes PJ. Airway inflammation and autonomic control. Eur J Respir Dis Suppl 1986a;147(80):80-7.

Barnes PJ. Neural control of human airways in health and disease. Am Rev Respir Dis 1986;134(6):1289-314.

Barnes PJ. Neurogenic inflammation in airways and its modulation. Arch Int Pharmacodyn Ther 1990;303:67-82.

Barnes PJ. Neurogenic inflammation in airways. Int Arch Allergy Appl Immunol 1991;94(1-4):303-9.

Barnes PJ. Therapeutic strategies for allergic diseases. Nature 1999;402(6760):B31-8.

Becker S, Soukup JM, Gilmour MI, Devlin RB. Stimulation of human and rat alveolar macrophages by urban air particulates: effects on oxidant radical generation and cytokine production. Toxicol Appl Pharmacol 1996;141(2):637-48.

Belmonte C, Garcia-Hirschfeld J, Galli SJ. Neurobiology of ocular pain. Prog Retinal Eye Res 1996;16:117-56. 
Bevan S, Hothi S, Hughes G, James IF, Rang HP, Shah K, Walpole CS, Yeats JC. Capsazepine: a competitive antagonist of the sensory neurone excitant capsaicin. Br J Pharmacol 1992;107(2): 544-52.

Brauer M, Dumyahn TS, Spengler JD, Gutschmidt K, Heinrich J, Wichmann HE. Measurement of acidic aerosol species in eastern Europe: implications for air pollution epidemiology. Environ Health Perspect 1995;103(5):482-8.

Brismar T. Physiology of transformed glial cells. Glia 1995;15(3): 231-43.

Burnett RT, Cakmak S, Raizenne ME, Stieb D, Vincent R, Krewski D, Brook JR, Philips O, Ozkaynak H. The association between ambient carbon monoxide levels and daily mortality in Toronto. Can J Air Waste Manage Assoc 1998;48(8):689-700.

Carter JD, Ghio AJ, Samet JM, Devlin RB. Cytokine production by human airway epithelial cells after exposure to an air pollution particle is metal-dependent. Toxicol Appl Pharmacol 1997;146(2):180-8.

Caterina MJ, Rosen TA, Tominaga M, Brake AJ, Julius D. A capsaicin-receptor homologue with a high threshold for noxious heat. Nature 1999;398(6726):436-41.

Chan KY, Haschke RH. Specificity of a neuronotrophic factor from rabbit corneal epithelial cultures. Exp Eye Res 1985;41(6):687-99.

Chen LC, Miller PD, Amdur MO, Gordon T. Airway hyperresponsiveness in guinea pigs exposed to acid-coated ultrafine particles. J Toxicol Environ Health 1992;35(3):165-74.

Colquhoun EQ, Eldershaw TP, Bennett KL, Hall JL, Dora KA, Clark MG. Functional and metabolic evidence for two different vanilloid (VN1 and VN2) receptors in perfused rat hindlimb. Life Sci 1995;57(2):91-102.

de Jongste JC, Jongejan RC, Kerrebijn KF. Control of airway caliber by autonomic nerves in asthma and in chronic obstructive pulmonary disease. Am Rev Respir Dis 1991;143(6):1421-6.

Devillier P, Advenier C, Drapeau G, Marsac J, Regoli D. Comparison of the effects of epithelium removal and of an enkephalinase inhibitor on the neurokinin-induced contractions of guinea-pig isolated trachea. Br J Pharmacol 1988;94(3):67584.

Di Maria GU, Bellofiore S, Geppetti P. Regulation of airway neurogenic inflammation by neutral endopeptidase. Eur Respir J 1998;12(6):1454-62.

Dockery DW, Pope CA. Acute respiratory effects of particulate air pollution. Annu Rev Public Health 1994;15:107-32.

Dockery DW, Schwartz J, Spengler JD. Air pollution and daily mortality: associations with particulates and acid aerosols. Environ Res 1992;59(2):362-73.

Dreher KL, Jaskot RH, Kodavanti U, Lehmann JR, Winsett DW, Costa DL. Soluble transition metals mediate the acute pulmonary injury and airway hyperreactivity induced by residual oil fly ash particles. Chest 1998;109(3):33S.

Dreher KL, Jaskot RH, Lehmann JR, Richards JH, McGee JK, Ghio AJ, Costa DL. Soluble transition metals mediate residual oil fly ash induced acute lung injury. J Toxicol Environ Health 1997;50(3):285-305.

Dye JA, Adler KB, Richards JH, Dreher KL. Epithelial injury by exposure to residual oil fly-ash particles-role of reactive oxygen species. Am J Respir Cell Mol Biol 1997;17(5):625-33.

Eichenbaum GM, Kiser PF, Simon SA, Needham D. pH and ion triggered volume response of anionic hydrogel microspheres. Macromolecules 1998;31(15):5084-93.
el-Fawal HA, McGovern T, Schlesinger RB. Nonspecific bronchial responsiveness assessed in vitro following acute inhalation exposure to ozone and ozone/sulfuric acid mixtures. Exp Lung Res 1995;21(1):129-39.

Elwood W, Lotvall JO, Barnes PJ, Chung KF. Airway hyperresponsiveness to acetylcholine and to tachykinins after respiratory virus infection in the guinea pig. Ann Allergy 1993;70(3):231-6.

Finlayson-Pitts BJ, Pitts Jr, JN. Tropospheric air pollution: ozone, airborne toxics, polycyclic aromatic hydrocarbons, and particles. Science 1997;276(5315):1045-52.

Folkerts G, Nijkamp FP. Airway epithelium: more than just a barrier. Trends Pharmacol Sci 1998;19(8):334-41.

Gagnaire F, Ban M, Cour C, Micillino JC, Bonnet P, Hettich D. Role of tachykinins and neutral endopeptidase in toluene diisocyanate- induced bronchial hyperresponsiveness in guinea pigs. Toxicology 1997;116(1):17-26.

Garcia-Hirschfeld J, Lopez-Briones LG, Belmonte C. Neurotrophic influences on corneal epithelial cells. Exp Eye Res 1994;59(5): 597-605.

Garle MJ, Knight A, Downing AT, Jassi KL, Clothier RH, Fry JR. Stimulation of dichlorofluorescin oxidation by capsaicin and analogues in RAW 264 monocyte/macrophages: lack of involvement of the vanilloid receptor. Biochem Pharmacol 2000; 59(5):563-72.

Gavett SH, Madison SL, Dreher KL, Winsett DW, McGee JK, Costa DL. Metal and sulfate composition of residual oil fly ash determines airway hyperreactivity and lung injury in rats. Environ Res 1997;72(2):162-72.

Gavett SH, Madison SL, Veronesi B. Capsaicin receptor antagonist and C-fiber depletion reduce pulmonary responses to particulate matter in BALB/c mice. The Toxicologists 1998; 18:405.

Gilmour PS, Brown DM, Lindsay TG, Beswick PH, MacNee W, Donaldson K. Adverse health effects of PM10 particles: involvement of iron in generation of hydroxyl radical. Occup Environ Med 1996;53(12):817-22.

Gold MS, Dastmalchi S, Levine JD. Co-expression of nociceptor properties in dorsal root ganglion neurons from the adult rat in vitro. Neuroscience 1996;71(1):265-75.

Gordon T, Sheppard D, McDonald DM, Distefano S, Scypinski L. Airway hyperresponsiveness and inflammation induced by toluene diisocyanate in guinea pigs. Am Rev Respir Dis 1985; 132(5):1106-12.

Gwynn RC, Burnett RT, Thurston GD. A time-series analysis of acidic particulate matter and daily mortality and morbidity in the buffalo. New York Region Environ Health Perspect 2000;108(2):125-33.

Hastings RH, Hua XY. Expression of calcitonin gene-related peptide by cultured rat alveolar type II cells. Am J Respir Cell Mol Biol 1995;13(5):563-9.

Hatch GE, Boykin E, Graham JA, Lewtas J, Pott F, Loud K, Mumford JL. Inhalable particles and pulmonary host defense: in vivo and in vitro effects of ambient air and combustion particles. Environ Res 1985;36(1):67-80.

Hayes AG, Scadding JW, Skingle M, Tyers MB. Effects of neonatal administration of capsaicin on nociceptive thresholds in the mouse and rat. J Pharm Pharmacol 1981;33(3): 183-5.

Henry WM, Knapp KT. Compound forms of fossil fuel fly ash emissions. Environ Sci Technol 1980;14(4):450-6. 
Hoek G, Brunekreef B, Verhoeff A, van Wijnen J, Fischer P. Daily mortality and air pollution in The Netherlands. J Air Waste Manage Assoc 2000;50(8):1380-9.

Hoi E, Mandys V, Sodaar P, Gispen WH, Bar PR. Protection by an ACTH analogue against the toxic effects of cisplatin and taxol on sensory neurons and glial cells in vitro. J Neurosci Res 1994;39:178-85.

Holian A, Hamilton RFJ, Morandi MT, Brown SD, Li L. Urban particle-induced apoptosis and phenotype shifts in human alveolar macrophages. Environ Health Perspect 1998;106(3): 127-32.

Holroyd KJ, Eleff SM, Zhang LY, Jakab GJ, Kleeberger SR. Genetic modeling of susceptibility to nitrogen dioxideinduced lung injury in mice. Am J Physiol 1997;273(1-3): L595-602.

Holt PG, Macaubas C, Stumbles PA, Sly PD. The role of allergy in the development of asthma. Nature 1999;402(6760):B12-7.

Hoyle GW, Graham RM, Finkelstein JB, Nguyen KP, Gozal D, Friedman M. Hyperinnervation of the airways in transgenic mice overexpressing nerve growth factor. Am J Respir Cell Mol Biol 1998;18(2):149-57.

Huggins FE, Huffman GP, Robertson JD. Speciation of elements in NIST particulate matter SRMs 1648 and 1650. J Hazard Mater 2000;74(1):1-23.

Hunter RJ. Zeta potential in colloid science. Principles Applic 1981;1:1-386.

Ichinose T, Takano H, Miyabara Y, Yanagisawa R, Sagai M. Murine strain differences in allergic airway inflammation and immunoglobulin production by a combination of antigen and diesel exhaust particles. Toxicology 1997;122(3):183-92.

Joad JP, Kott KS, Bric JM. The local C-fiber contribution to ozone-induced effects on the isolated guinea pig lung. Toxicol Appl Pharmacol 1996;141(2):561-7.

Joos GF, Germonpre PR, Pauwels RA. Role of tachykinins in asthma. Allergy 2000;55(4):321-37.

Kadiiska MB, Mason RP, Dreher KL, Costa DL, Ghio AJ. In vivo evidence of free radical formation in the rat lung after exposure to an emission source air pollution particle. Chem Res Toxicol 1997;10(10):1104-8.

Khair OA, Davies RJ, Devalia JL. Bacterial-induced release of inflammatory mediators by bronchial epithelial cells. Eur Respir J 1996;9(9):1913-22.

Kimmel TA, Chen LC, Bosland MC, Nadziejko C. Influence of acid aerosol droplet size on structural changes in the rat lung caused by acute exposure to sulfuric acid and ozone. Toxicol Appl Pharmacol 1997;144(2):348-55.

Kirischuk S, Pronchuk N, Verkhratsky A. Measurements of intracellular calcium in sensory neurons of adult and old rats. Neuroscience 1992;50(4):947-51.

Kleeberger SR. Genetic susceptibility to ozone exposure. Toxicol Lett 1995, pages 82-3, 295-300.

Kodavanti UP, Jaskot RH, Costa DL, Dreher KL. Pulmonary proinflammatory gene induction following acute exposure to residual oil fly ash - roles of particle-associated metals. Inhal Tox 1997a;9:679-701.

Kodavanti UP, Jaskot RH, Su WY, Costa DL, Ghio AJ, Dreher KL. Genetic variability in combustion particle-induced chronic lung injury. Am J Physiol 1997;272(1-3):L521-32.

Koenig JQ, Pierson WE. Air pollutants and the respiratory system: toxicity and pharmacologic interventions. J Toxicol Clin Toxicol 1991;29(3):401-11.
Kress M, Reeh PW, Vyklicky L. An interaction of inflammatory mediators and protons in small diameter dorsal root ganglion neurons of the rat. Neurosci Lett 1997;224(1):37-40.

Kuenzi FM, Dale N. Effect of capsaicin and analogues on potassium and calcium currents and vanilloid receptors in Xenopus embryo spinal neurones. Br J Pharmacol 1996;119(1):81-90.

Ladenius AR, Folkerts G, van der Linde HJ, Nijkamp FP. Potentiation by viral respiratory infection of ovalbumin-induced guinea- pig tracheal hyperresponsiveness: role for tachykinins. Br J Pharmacol 1995;115(6):1048-52.

Laitinen LA, Heino M, Laitinen A, Kava T, Haahtela T. Damage of the airway epithelium and bronchial reactivity in patients with asthma. Am Rev Respir Dis 1985;131(4):599-606.

Lammers JW, Barnes PJ, Chung KF. Nonadrenergic, noncholinergic airway inhibitory nerves. Eur Respir J 1992;5(2):239-46.

Lazarus SC. Role of inflammation and inflammatory mediators in airways disease. Am J Med 1986;81(5A):2-7.

Li XY, Gilmour PS, Donaldson K, MacNee W. Free radical activity and pro-inflammatory effects of particulate air pollution (PM10) in vivo and in vitro. Thorax 1996;51(12):1216-22.

Liao D, Creason J, Shy C, Williams R, Watts R, Zweidinger R. Daily variation of particulate matter and poor cardiac autonomic control in the elderly. Environ Health Perspect 1999;107(7): $521-5$.

Lippmann M, Thurston GD. Sulfate concentrations as an indicator of ambient particulate matter air pollution for health risk evaluations. J Exp Anal Environ Epidemiol 1996;6(2):123-46.

Lundberg JM. Tachykinins, sensory nerves, and asthma-an overview. Can J Physiol Pharmacol 1995;73(7):908-14.

Maggi CA. Tachykinin receptors and airway pathophysiology. Eur Respir J 1993;6(5):735-42.

Marz P, Cheng JG, Gadient RA, Patterson PH, Stoyan T, Otten U, Rose-John S. Sympathetic neurons can produce and respond to interleukin 6. Proc Natl Acad Sci USA 1998;95(6):3251-6.

McDonald DM. Neurogenic inflammation in the rat trachea. Part I. Changes in venules, leucocytes and epithelial cells. J Neurocytol 1988;17(5):583-603.

McKinnon KP, Madden MC, Noah TL, Devlin RB. In vitro ozone exposure increases release of arachidonic acid products from a human bronchial epithelial cell line. Toxicol Appl Pharmacol 1993;118(2):215-23.

McMillian M, Kong LY, Sawin SM, Wilson B, Das K, Hudson P, Hong JS, Bing G. Selective killing of cholinergic neurons by microglial activation in basal forebrain mixed neuronal/glial cultures. Biochem Biophys Res Commun 1995;215(2):572-7.

Meggs WJ. Neurogenic inflammation and sensitivity to environmental chemicals. Environ Health Perspect 1993;101(3):234-8.

Mills PR, Davies RJ, Devalia JL. Airway epithelial cells, cytokines, and pollutants. Am J Respir Crit Care Med 1999;160(5):S38-43.

Miyabara Y, Yanagisawa R, Shimojo N, Takano H, Lim HB, Ichinose T, Sagai M. Murine strain differences in airway inflammation caused by diesel exhaust particles. Eur Respir J 1998;11(2):291-8.

Mudpalli A. Involvement of calcium and calcium channels in residual oil fly ash and silica-induced stimulation of human alveolar macrophages. Third Colloquium on Particulate Matter and Human Health, Durham, NC. 1999.

Mullol J, Baraniuk JN, Pitale M, Benfield T, Logun C, Picado C, Shelhamer JH. Vasoactive intestinal peptide (VIP) induces IL-6 and IL-8, but not G-CSF and GM-CSF release from a human bronchial epithelial cell line. Neuropeptides 1997;31(2):119-24. 
Murphy PG, Grondin J, Altares M, Richardson PM. Induction of interleukin-6 in axotomized sensory neurons. J Neurosci 1995;15(2-7):5130-8.

Nielsen GD. Mechanisms of activation of the sensory irritant receptor by airborne chemicals. Crit Rev Toxicol 1991;21(3): 183-208.

Ogun-Muyiwa P, Helliwell R, McIntyre P, Winter J. Glial cell line derived neurotrophic factor (GDNF) regulates VR1 and substance $\mathrm{P}$ in cultured sensory neurons. Neuroreport 1999; 10(10):2107-11.

Ohtoshi T, Takizawa H, Sakamaki C, Ishii A, Hirai K, Morita Y, Ito K, Ohta K, Mano K, Suzuki S. Cytokine production by human airway epithelial cells and its modulation. Nihon Kyobu Shikkan Gakkai Zasshi 1994;32:65-72.

Oortgiesen M, Veronesi B, Eichenbaum GM, Simon, SA. Residual oil fly ash (ROFA) and negatively charged synthetic polymers activate bronchial epithelial cells and nociceptive sensory neurons. Am J Physiol Lung Cell Mol Physiol 2000;278(4): L683-95.

Palma C, Minghetti L, Astolfi M, Ambrosini E, Silberstein FC, Manzini S, Levi G, Aloisi F. Functional characterization of substance P receptors on cultured human spinal cord astrocytes: synergism of substance $\mathrm{P}$ with cytokines in inducing interleukin-6 and prostaglandin E2 production. Glia 1997;21(2): 183-93.

Piedimonte G, Hoffman JI, Husseini WK, Hiser WL, Nadel JA. Effect of neuropeptides released from sensory nerves on blood flow in the rat airway microcirculation. J Appl Physiol 1992; 72(4): 1563-70.

Polito AJ, Proud D. Epithelia cells as regulators of airway inflammation. J Allergy Clin Immunol 1998;102(5):714-8.

Pope CA. Particulate pollution and health: a review of the Utah valley experience. J Exposure Anal Environ Epidemiol 1996; 6(1):23-34.

Pope CA. Epidemiological 2000: basisfor particulate air pollution health standards. Aerosol Sci Technol 2000;324:314.

Prior M, Green F, Lopez A, Balu A, De Sanctis GT, Fick G. Capsaicin pretreatment modifies hydrogen sulphide-induced pulmonary injury in rats. Toxicol Pathol 1990;18(2):279-88.

Pritchard R, Ghio AJ, Lehmann JR, Winsett DW, Tepper JS, Park P, Girolomoni G, Dreher KL, Costa DL. Oxidant generation and lung injury after particulate air pollution exposure increase with the concentration of associated metals. Inhal Toxicol 1996;8: 457-77.

Rahman Q, Norwood J, Hatch G. Evidence that exposure of particulate air pollutants to human and rat alveolar macrophages leads to differential oxidative response. Biochem Biophys Res Commun 1997;240(3):669-72.

Reddel RR, Ke Y, Gerwin BI, McMenamin MG, Lechner JF, Su RT, Brash DE, Park JB, Rhim JS, Harris CC. Transformation of human bronchial epithelial cells by infection with SV40 or adenovirus-12 SV40 hybrid virus, or transfection via strontium phosphate coprecipitation with a plasmid containing SV40 early region genes. Cancer Res 1988;48(7):1904-9.

Samet J, Zeger S, Dominici F, Curriero F, Coursac I, Dockery DW, Schwartz J, Zanobetti A. The national norbidity, mortality and air pollution study. Part II. Morbidity and mortality from air pollution in the United States. Health Headlines 2000;94:1-79.

Samet JM, Noah TL, Devlin RB, Yankaskas JR, McKinnon K, Dailey LA, Friedman M. Effect of ozone on platelet-activating factor production in phorbol-differentiated HL60 cells, a human bronchial epithelial cell line (BEAS S6), and primary human bronchial epithelial cells. Am J Respir Cell Mol Biol 1992; 7(5):514-22.

Samet JM, Stonehuerner J, Reed W, Devlin RB, Dailey LA, Kennedy TP, Bromberg PA, Ghio AJ. Disruption of protein tyrosine phosphate homeostasis in bronchial epithelial cells exposed to oil fly ash. Am J Physiol 1997;272(1-3):L42632.

Satoh H, Lou YP, Lundberg JM. Inhibitory effects of capsazepine and SR 48968 on citric acid-induced bronchoconstriction in guinea-pigs. Eur J Pharmacol 1993;236(3):367-72.

Savitha G, Panchanathan S, Salimath BP. Capsaicin inhibits calmodulin-mediated oxidative burst in rat macrophages. Cell Signal 1990;2(6):577-85.

Scheerens H, Buckley TL, Muis T, Van Loveren H, Nijkamp FP. The involvement of sensory neuropeptides in toluene diisocyanate-induced tracheal hyperreactivity in the mouse airways. Br J Pharmacol 1996;119(8):1665-71.

Schwartz J. What are people dying of on high air pollution days. Environ Res 1994;64(1):26-35.

Schwartz J. Air pollution and hospital admissions for respiratory disease. Epidemiology 1996;7(1):20-8.

Sennet P, Olivier JP. Colloidal dispersions, electrokinetic effects and the concept of zeta potential. In: Ross S, editor. Chemistry of Physics of interfaces, Washington, DC: American Chemical Society, 1965;73-93.

Sheppard D, Scypinski L. A tachykinin receptor antagonist inhibits and an inhibitor of tachykinin metabolism potentiates toluene diisocyanate-induced airway hyperresponsiveness in guinea pigs. Am Rev Respir Dis 1988;138(3):547-51.

Shu X, Mendell LM. Nerve growth factor acutely sensitizes the response of adult rat sensory neurons to capsaicin. Neurosci Lett 1999;274(3):159-62.

Solway J, Leff AR. Sensory neuropeptides and airway function. J Appl Physiol 1991;71(6):2077-87.

Springall DR, Edginton JA, Price PN, Swanston DW, Noel C, Bloom SR, Polak JM. Acrolein depletes the neuropeptides CGRP and substance $\mathrm{P}$ in sensory nerves in rat respiratory tract. Environ Health Perspect 1990;85:151-7.

Stevens TP, McBride JT, Peake JL, Pinkerton KE, Stripp BR. Cell proliferation contributes to PNEC hyperplasia after acute airway injury. Am J Physiol 1997;272(1-3):L486-93.

Su WY, Kodavanti UP, Jaskot RH, Costa DL, Dreher KL. Temporal expression and cellular distribution of pulmonary fibronectin gene induction following exposure to an emission source particle. J Environ Pathol Toxicol Oncol 1995;14(3): 215-25.

Szallasi A. The vanilloid (capsaicin) receptor: receptor types and species differences. Gen Pharmacol 1994;25(2):223-43.

Szallasi A, Blumberg PM. $[3 \mathrm{H}]$ resiniferatoxin binding by the vanilloid receptor: species-related differences, effects of temperature and sulfhydryl reagents. Naunyn Schmiedebergs Arch Pharmacol 1993;347(1):84-91.

Thomas DJ, Fisher HL, Sumler MR, Hall LL, Mushak P. Distribution and retention of organic and inorganic mercury in methyl mercury-treated neonatal rats. Environ Res 1988;47(1): 59-71.

Tonnel AB, Marquette C, Wallaert B. Physiopathology of asthma. Rev Prat 1992;42(19):2399-404.

Utell MJ, Frampton MW. Who is susceptible to particulate matter and why. Inhal Toxicol 2000;12(1):37-40. 
Utell MJ, Frampton MW, Morrow PE. Air pollution and asthma: clinical studies with sulfuric acid aerosols. Allergy Proc 1991; 12(6):385-8.

Veronesi B, de Haar C, Roy J, Oortgiesen M. Particulate matter inflammation and receptor sensitivity are target cell specific. Inhal Toxicol, in press.

Veronesi B, Oortgiesen M, Roy J, Carter JD, Simon SA, Gavett SH. Vanilloid (capsaicin) receptors influence inflammatory sensitivity in response to particulate matter. Toxicol Appl Pharmacol 2000;169:66-76.

Veronesi B, Carter JD, Devlin RB, Simon SA, Oortgiesen M. Neuropeptides and capsaicin stimulate the release of proinflammatory cytokines in a human bronchial epithelial cell line. Neuropeptides 1999a;33(6):447-56.

Veronesi B, Oortgiesen M, Carter JD, Devlin RB. Particulate matter (PM) initiates inflammatory cytokine release by activation of capsaicin receptors in a human bronchial epithelial cell line. Toxicol Appl Pharmacol 1999;154(1):106-15.

Wasserman SI. Basic mechanisms in asthma. Ann Allergy 1988; 60(5):477-82.

White SR, Garland A, Gitter B, Rodger I, Alger LE, Necheles J, Nawrocki AR, Solway J. Proliferation of guinea pig tracheal epithelial cells in co-culture with rat dorsal root ganglion neural cells. Am J Physiol 1995;268(1-6):L95765 .
Widdicombe J. The tracheobronchial vasculature: a possible role in asthma. Microcirculation 1996;3(2):129-41.

Widdicombe JG. Sensory innervation of the lungs and airways. Prog Brain Res 1986;67:49-64.

Widdicombe JG, Neuroregulation of the nose and bronchi. Clin Exp Allergy 1996a;3(26 Suppl):32-5.

Winter J, Walpole CS, Bevan S, James IF. Characterization of resiniferatoxin binding sites on sensory neurons: co-regulation of resiniferatoxin binding and capsaicin sensitivity in adult rat dorsal root ganglia. Neuroscience 1993;57(3):747-57.

Wood JN, Docherty R. Chemical activators of sensory neurons. Annu Rev Physiol 1997;59:457-82.

Wood JN, Winter J, James IF, Rang HP, Yeats J, Bevan S. Capsaicin-induced ion fluxes in dorsal root ganglion cells in culture. J Neurosci 1988;8(9):3208-20.

Yeadon M, Wilkinson D, Darley-Usmar V, O'Leary VJ, Payne AN. Mechanisms contributing to ozone-induced bronchial hyperreactivity in guinea-pigs. Pulm Pharmacol 1992;5(1):39-50.

Zelikoff JT, Frampton MW, Cohen MD, Morrow PE, Sisco M, Tsai Y, Utell MJ, Schlesinger RB. Effects of inhaled sulfuric acid aerosols on pulmonary immunocompetence-a comparative study in humans and animals. Inhal Toxicol 1997;9:731-52.

Zhang LY, Levitt RC, Kleeberger SR. Differential susceptibility to ozone-induced airways hyperreactivity in inbred strains of mice. Exp Lung Res 1995;21(4):503-18. 